\title{
CADMIUM SORPTION BY DRIED PLANT BIOMASS - REVERSIBILITY STUDIES
}

\author{
KRISTÍNA MURÁŇOVÁ, JANA MAREŠOVÁ, \\ MIROSLAV HORNÍK, JOZEF AUGUSTIIN \\ Department of Ecochemistry and Radioecology, \\ University of SS. Cyril and Methodius in Trnava, J. Herdu 2, Trnava, SK-917 01, \\ SlovakRepublic (jana.maresova@ucm.sk)
}

\begin{abstract}
Heavy metals such as cadmium are hazardous to biosystems and present possible human health risk. Thus, the removal of cadmium from liquid wastes is of great importance from an environmental and industrial point of view. There is a tendency to use agricultural wastes for the sorption of toxic metals as an alternative to the existing conventional technologies. The aim of this work was to describe $\mathrm{Cd}$ sorption and desorption equilibria by dried leaf biomass of tobacco (Nicotiana tabacum L.), hop (Humulus lupulus L.), pumpkin (Cucurbita pepo L.), sunflower (Helianthus annuus L.), cucumber (Cucumis sativus L.), pepper (Capsidum annuит L.), tomato (Solanum lycopersicum L.) and vine-grape (Vitis vinifera L.) using radiotracer technique with ${ }^{109} \mathrm{CdCl}_{2}$. Cadmium sorption $Q$ values $(\mathrm{mg} / \mathrm{g}$, d.w.) of all of plant biomass studied increased proportionally with the initial $\mathrm{CdCl}_{2}$ concentration within the range $0.01-10 \mathrm{mmol} / \mathrm{L} \mathrm{CdCl}_{2}$. Mean sorption capacity of dried leaf biomasses of eight plants for $\mathrm{Cd}$ from the solution with the initial concentration $C_{0}=10 \mathrm{mmol} / \mathrm{L} \mathrm{CdCl}_{2}$ in deionized water was $Q=213 \mu \mathrm{mol} / \mathrm{g}$ (d.w.). By single step desorption of $\mathrm{Cd}$ from leaf biomass for 30 minat $20{ }^{\circ} \mathrm{C}$ with deionized water, $0.1 \mathrm{mmol} / \mathrm{L}$ EDTA or 0.1 $\mathrm{mmol} / \mathrm{L} \mathrm{HCl}$, up to $30 \%, 85 \%$ and $98 \%$ of sorbed Cd, respectively, was removed. Obtained data can serve as a model for the prediction of sorption-desorption equilibria of biomass used for removing of $\mathrm{Cd}$ from polluted waters and $\mathrm{Cd}$ releasing back into waters containing other inorganic solutes. Formation of $\mathrm{Cd}^{2+}$, $\mathrm{CdCl}^{+}, \mathrm{CdCl}_{2}{ }^{0}, \mathrm{CdSO}_{4}{ }^{0}, \mathrm{CdOH}^{+}, \mathrm{Cd}_{2} \mathrm{OH}_{3}{ }^{+}, \mathrm{Cd}(\mathrm{OH})_{2}{ }^{0}$ and $\mathrm{Cd}(\mathrm{OH})_{3}{ }_{3}^{-}$species in dependence on $\mathrm{pH}$ values and the presence of $\mathrm{Cl}^{-}$anions is also discussed.
\end{abstract}

Key words: cadmium, ${ }^{109} \mathrm{CdCl}_{2}$, sorption, desorption, plant biomass

\section{Introduction}

Cadmium is one of the most toxic metals found in effluents discharged from industries involved in metal plating, metallurgical alloying, mining, ceramics and other industrial activities. Also, there is growing environmental concern about $\mathrm{Cd}$ as being one of the most ecotoxic metals that exhibit highly adverse effects on soil biological activity, plant metabolism and the health of humans. USEPA has also classified cadmium as group B1 carcinogen (USEPA, 1999). The behaviour of $\mathrm{Cd}$ in the environment and related health aspects has been reviewed by KABATA-PENDIAS and PENDIAS (2001).

Broad spectrum of sorbents has received increased attention for heavy metal removal. Data were published in numerous original papers and patents. For reviews see e.g. SINGH and TRIPATHI (2007), SUD et al. (2008). Several physical and chemical methods have been used for removal of heavy metals from industrial liquid wastes, such as ion-exchange, chemical precipitation, chemical reduction and 
adsorption. There are still problems associated with these methods mainly these are cost-expensive and can themselves produce other wastes, which has limited their industrial applications. Among the available treatment processes, the application of biological sorbents is the most promising due to the following reasons: requirement of chemicals for the treatment process is reduced, lower operating costs, eco-friendly, higher efficiency at low levels of contaminations and cost-effective alternative of conventional techniques.

In our previous papers we described sorption characteristics of $\mathrm{Co}, \mathrm{Zn}$ and $\mathrm{Cd}$ binding by dry biomass of lichen E. prunastri (PIPÍŠKA et al., 2008) and moss R. squarrosus (PIPÍŠKA et al., 2010) and by biomass of activated sludge of waste water treatment plant (MAREŠOVÁ et al., 2010). The objective of this study was to obtain quantitative data of cadmium sorption by dried leaf biomass of common agricultural plants and reversibility of the sorption-desorption processes.

\section{Materials and methods}

\subsection{Plant biomass}

Leaves of sunflower (Helianthus annuus L.), pumpkin (Cucurbita pepo L.), cucumber (Cucumis sativus L.), pepper (Capsidum annuum L.), tomato (Solanum lycopersicum L.) collected from plants growing in garden (Trnava region) and leaves of vine-grape (Vitis vinifera L.) from vineyard (Malé Karpaty region) in the middle of summer period.

Tobacco (Nicotiana tabacum L.) and hop (Humulus lupulus L.) leaves were obtained from plants cultivated in laboratory at $22{ }^{\circ} \mathrm{C}$ at light/dark period $12 / 12 \mathrm{~h}$ (2 $000 \mathrm{~lx}$ ). Seeds of tobacco were germinated and grown in pots filled with granulated perlite watered with diluted Hoagland medium pH 7.0 (HOAGLAND, 1920). Hop plants (variety Osvald clone 72, genotype K-72/6/13) were obtained from the Research Institute of Plant Production in Piešt'any (SK).

Detached leaves were dried for 3 days at $60{ }^{\circ} \mathrm{C}$, pulverized by rotatory knife blender and sieved by normalized sieves. Fractions $<0.45 \mathrm{~mm}$ were used for experiments.

\subsection{Sorption experiments}

A batch equilibrium method was used to determine sorption of $\mathrm{Cd}$ by dried leaf biomass of 8 plants. In plastic test tubes $(10 \mathrm{~mL}) 0.05 \mathrm{~g}$ of dried biomass was mixed with $2 \mathrm{~mL} \mathrm{CdCl}_{2}$ solution in deionized water $(0.01-10 \mathrm{mmol} / \mathrm{L})$, spiked with ${ }^{109} \mathrm{CdCl}_{2}$ and placed on reciprocal shaker $\left(200 \mathrm{~min}^{-1}\right)$ at $20{ }^{\circ} \mathrm{C}$. Preliminary experiments showed that $10 \mathrm{~min}$ reaction time is sufficient for reaching of sorption equilibrium. For sorption experiments the initial $\mathrm{pH}$ value of solutions was adjusted to $\mathrm{pH} 5.0$ with $1.0 \mathrm{M} \mathrm{NaOH}$. Biomass was separated by centrifugation for $20 \mathrm{~min}$ at $2800 \times \mathrm{g}$ and both sediments and liquid phase were analysed by gamma spectrometry. The experiments were conducted in triplicate. The amount of sorbed $\mathrm{Cd}$ ( $\mu \mathrm{mol} \mathrm{Cd} / \mathrm{g} \mathrm{d}$.w.) was calculated according to the following equation: 


$$
Q=\frac{V^{*}\left(C_{0}-C_{e q}\right)}{m}
$$

where $Q$ is the specific Cd uptake ( $\mu$ mol $\mathrm{Cd} / \mathrm{g}$ biomass d.w.); $V$ is the volume of $\mathrm{Cd}$ solution (L); $C_{0}$ is the initial concentration of $\mathrm{Cd}$ in the solution $(\mathrm{mmol} / \mathrm{L}) ; C_{e q}$ is the concentration of $\mathrm{Cd}$ in the solution in equilibrium $(\mathrm{mmol} / \mathrm{L})$ and $m$ is mass of the dried biosorbent $(\mathrm{g})$.

\subsection{Desorption experiments}

Biomass ( $0.05 \mathrm{~g}$, d.w.) after sorption experiments was separated by centrifugation for $20 \mathrm{~min}$ at $2800 \times \mathrm{g}$ and resuspended by wortexing for $30 \mathrm{~min}$ in $5.0 \mathrm{~mL}$ deionized water, $1.0 \mathrm{~mL} 0.1 \mathrm{M}$ EDTA or $1.0 \mathrm{~mL} 0.1 \mathrm{M} \mathrm{HCl}$. Cd concentrations in biomass and in extracts were estimated by similar way as in the sorption experiments.

\subsection{Radiometric and speciation analysis}

A gamma spectrometric assembly using the well type scintillation detector 54BP54/2-X, NaI(Tl) (Scionix, NL) and data processing software ScintiVision-32 (ORTEC, USA) were used for $\mathrm{Cd}$ determination in biomass and supernatants. A library of radionuclides was built by selecting characteristic $\gamma$-ray peaks $(88.04 \mathrm{keV}$ for ${ }^{109} \mathrm{Cd}, 661.66 \mathrm{keV}$ for ${ }^{137} \mathrm{Cs}, 834.81 \mathrm{keV}$ for ${ }^{54} \mathrm{Mn}$ and $1115.52 \mathrm{keV}$ for ${ }^{65} \mathrm{Zn}$ ) for energy and efficiency calibration. Counting time $600 \mathrm{~s}$ allowed obtaining data with measurement error $<2 \%$, which do not reflect other source of errors. Standardized solution of ${ }^{109} \mathrm{CdCl}_{2}(3.94 \mathrm{MBq} / \mathrm{mL}, 50 \mathrm{mg} / \mathrm{L} \mathrm{CdCl} 2$ in $3 \mathrm{~g} / \mathrm{L} \mathrm{HCl})$ was obtained from The Czech Institute of Metrology (Prague, CR). Cd speciation in the solution as a function of $\mathrm{pH}$ and concentration of $\mathrm{Cl}^{-}$anions was performed using the Visual MINTEQ (ver. 3.0) modelling software.

\section{Results and discussions}

\subsection{Cadmium sorption}

Sorption experiments showed that dried leaf biomass is able to bind remarkable amounts of cadmium. $Q$ values ( $\mu \mathrm{mol} / \mathrm{g}, \mathrm{d}$.w.) at biomass concentration $25 \mathrm{~g} / \mathrm{L}$ (d.w.) are proportional to the initial $\mathrm{CdCl}_{2}$ concentration within the range studied $0.01-10 \mathrm{mmol} / \mathrm{L} \mathrm{CdCl}_{2}$. However as can be seen from the data in Fig. 1 even at initial concentration $C_{0}=10 \mathrm{mmol} / \mathrm{L} \mathrm{CdCl}_{2}$ plant sorbents were not saturated under given conditions and higher $Q_{\max }$ values at saturation of sorbent can be expected.

Sorption capacity $Q$ of the dried leaf biomass of studied plants differs within the same order, ranging from 145 to $289 \mu \mathrm{mol} / \mathrm{g}$ (d.w.), despite of different taxonomic classification (Tab. 1).

In Table 2, the value sorption capacities $Q(\mathrm{mg} / \mathrm{g} \mathrm{Cd}$, d.w.) for naturally occurring sorbents are presented. We can conclude that studied plant biomasses showed similar results in comparison with others inorganic, organic and biological sorbents origin. 


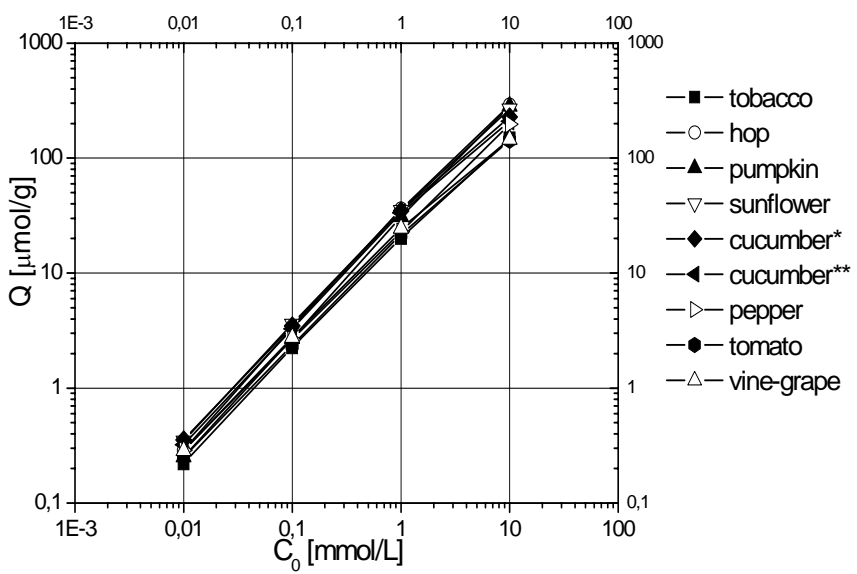

Fig. 1. Cadmium sorption $Q$ ( $\mu \mathrm{mol} / \mathrm{g}$; d.w.) by dried leaf biomass of different plants $(25 \mathrm{~g} / \mathrm{L}$, d.w. $)$ in dependence on initial $\mathrm{CdCl}_{2}$ concentration. Data after 10 min reaction at $20^{\circ} \mathrm{C}, \mathrm{pH} 5.0$ are the mean of three replicates. ${ }^{*}$ C. sativus $\mathrm{L}$. convar. longus, ${ }^{* *}$ C. sativus $\mathrm{L}$. convar. viridis

Table 1. Cadmium sorption $Q$ ( $\mu \mathrm{mol} / \mathrm{g}$; d.w.) by dried leaf biomass $(25 \mathrm{~g} / \mathrm{L}$, d.w.) of different plants after 10 min reaction in $10 \mathrm{mmol} / \mathrm{L} \mathrm{CdCl} 2$ in deionized water at $20^{\circ} \mathrm{C}, \mathrm{pH}$ 5.0. Data are the mean of three replicates.

\begin{tabular}{lcc}
\hline \multicolumn{1}{c}{ Plant } & Family & $\begin{array}{c}Q \\
{[\mu \mathrm{mol} / \mathrm{g}]}\end{array}$ \\
\hline Humulus lupulus L. & Cannabaceae & $288.8 \pm 3.8$ \\
Cucurbita pepo L. & Cucurbitaceae & $283.1 \pm 8.7$ \\
Helianthus annuus L. & Asteraceae & $268.4 \pm 5.6$ \\
Cucumis sativus L. convar. Longus & Cucurbitaceae & $228.4 \pm 7.6$ \\
Cucumis sativus L. convar. viridis & Cucurbitaceae & $209.7 \pm 6.1$ \\
Capsicum annum L. & Solanaceae & $196.9 \pm 4.3$ \\
Nicotiana tabacum L. & Solanaceae & $148.8 \pm 4.0$ \\
Solanum lycopersicum L. & Solanaceae & $147.2 \pm 4.0$ \\
Vitis vinifera L. & Vitaceae & $145.0 \pm 2.0$ \\
\hline
\end{tabular}

Table 2. Sorption capacities $Q(\mathrm{mg} / \mathrm{g} \mathrm{Cd}$; d.w.) of naturally occuring sorbents.

\begin{tabular}{lcclcc}
\hline Sorbent & $\begin{array}{c}Q \\
{[\mathrm{mg} / \mathrm{g}]}\end{array}$ & Ref. & Sorbent & $\begin{array}{c}Q \\
{[\mathrm{mg} / \mathrm{g}]}\end{array}$ & Ref. \\
\hline Bark & 32 & 3 & Activated sludge & 121 & 2 \\
Chitosan & 558 & 3 & Hop leaves & 32.5 & 4 \\
Clay & 16.5 & 3 & Pumpkin leaves & 31.8 & 4 \\
Microbial biomass & 28 & 3 & Sunflower leaves & 30.2 & 4 \\
Modified wool & 87 & 3 & Cucumber leaves* & 25.7 & 4 \\
Peat & 5.1 & 3 & Cucumber leaves** & 23.6 & 4 \\
Seaweed & 215 & 3 & Pepper leaves & 22.1 & 4 \\
Xanthate & 33.3 & 3 & Tobacco leaves & 16.7 & 4 \\
Zeolite & 84.3 & 3 & Tomato leaves & 16.5 & 4 \\
Moss biomass & 19.4 & 1 & Vine leaves & 16.3 & 4 \\
\hline
\end{tabular}

(1) PIPÍŠKA et al., 2010; (2) MAREŠOVÁ et al., 2010; (3 ) BAILEY et al., 1999; (4) This paper.

${ }^{*}$ C. sativus $\mathrm{L}$. convar. longus, ${ }^{* *}$ C. sativus $\mathrm{L}$. convar. viridis 


\subsection{The influence of $\mathrm{pH}$}

It is generally accepted that the $\mathrm{pH}$ optimum of biosorption for bivalent metal cations is within $\mathrm{pH} 4-6$. In strong acid media the efficiency of cation sorption is minimal due to competitive effect of $\mathrm{H}^{+}$ions. In alkaline region the situation is more complicated due to the existence of multiple $\mathrm{Cd}$ species. Data obtained by speciation program Visual MINTEQ shows that eight Cd species can exist in alkaline solutions. Molar fractions of cationic, anionic and nonionic forms of $\mathrm{Cd}$ expressed in molar fraction $X$ in dependence on $\mathrm{pH}$ value are shown in Fig. 2.

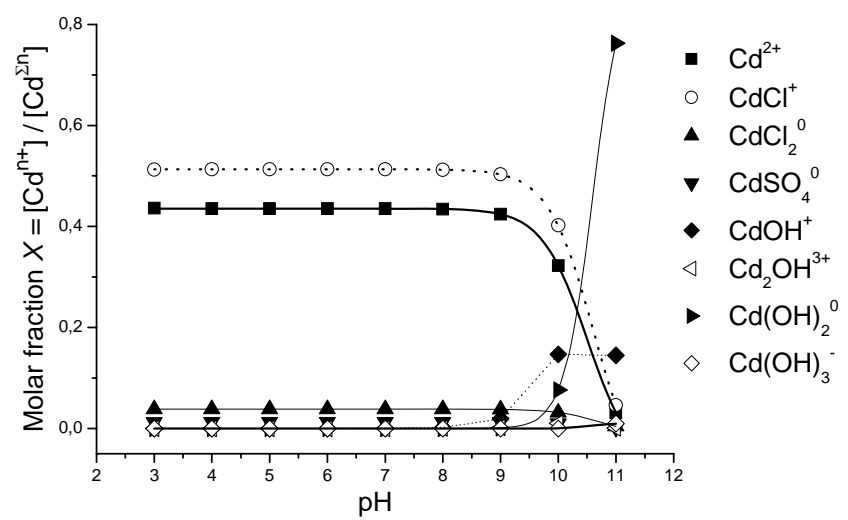

Fig. 2. Molar fraction $X$ of cadmium species in dependence on solution $\mathrm{pH}$ at concentration $10 \mathrm{mmol} / \mathrm{L}$ $\mathrm{CdCl}_{2}{ }^{\circ}$ and $20{ }^{\circ} \mathrm{C}$. Solution of inorganic salts corresponding to synthetic waste water according to IAQUINTA et al. (2006) (ppm): $\mathrm{Cl}^{-}-455 ; \mathrm{SO}_{4}{ }^{2-}-87 ; \mathrm{Na}^{+}-418 ; \mathrm{K}^{+}-78 ; \mathrm{Mg}^{2+}-45 ; \mathrm{Ca}^{2+}-138$. Calculated by Visual MINTEQ ver. 3.0.

As can be seen from the data in Fig. 2, prevailing part of $\mathrm{Cd}$ is present in $\mathrm{Cd}^{2+}$ form $(42 \%)$ and $\mathrm{CdCl}^{+}$form $(51 \%)$ and this proportion stay the same within $\mathrm{pH}$ range from $\mathrm{pH} 3.0$ to $\mathrm{pH}$ 8.5. Concentration of $\mathrm{Cd}(\mathrm{OH})_{2}{ }^{0}$ increases above $\mathrm{pH}$ 9. During the sorption of metals by sorbents from alkaline liquid wastes besides sorption of $\mathrm{Cd}^{2+}$ cations also the existence of other than ionic metal forms with different solubility in water have to be taken into consideration. Similar data was obtained also by GUIBAUD et al. (2009), where sigmoidal $\mathrm{pH}$ dependence of $\mathrm{Cd}^{2+}$ sorption by polysaccharides of activated sludge with inflection point at $\mathrm{pH} 8.6$ was observed.

\subsection{The influence of $\mathrm{Cl}^{-}$ions}

As can be seen from the data in Fig. 3, molar fraction $X$ of $\mathrm{Cd}^{2+}$ significantly decreases in the presence of $\mathrm{Cl}^{-}$ions up to $10^{-1} \mathrm{~mol} / \mathrm{L} \mathrm{NaCl}$, as a result of the increase of $\mathrm{CdCl}^{+}$molar fraction. At $1.0 \mathrm{~mol} / \mathrm{L} \mathrm{NaCl}\left(5.8 \%\right.$, w/v) concentration of $\mathrm{Cd}^{2+}$ is minimal and prevailing $\mathrm{Cd}$ species are non dissociated $\mathrm{CdCl}_{2}{ }^{0}$ or $\mathrm{CdCl}^{+}$.

In interactions of biosorbents with $\mathrm{Cd}(\mathrm{II})$ in the presence of $\mathrm{Cl}^{-}$anions, what is typical for many kinds of liquid wastes, the existence of complex mixture of different $\mathrm{Cd}$ species can be expected. Mechanism of $\mathrm{Cd}$ biosorption will then depend both on the $\mathrm{pH}$ values of liquid phase, as well as on the concentration of other solutes, mainly 
$\mathrm{Cl}^{-}$salts, but also on the presence of other solutes able to form complexes with high values of stability constants $\log K$.

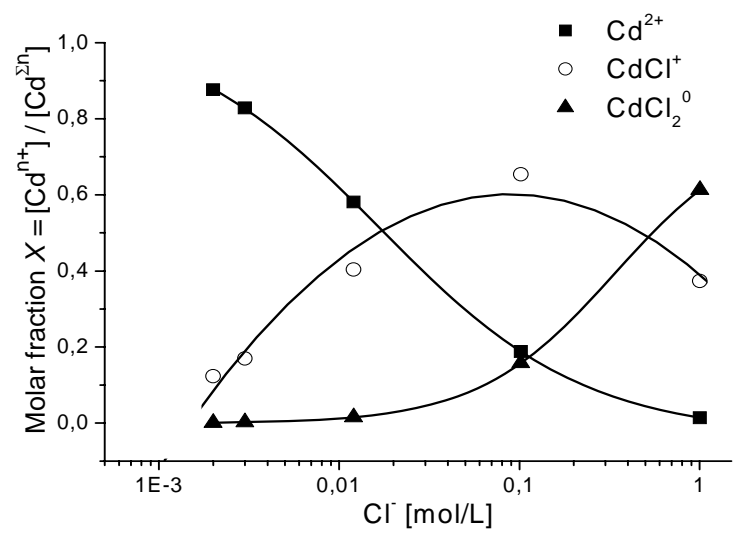

Fig. 3. Molar fraction $X$ of $\mathrm{Cd}^{2+}, \mathrm{CdCl}^{+}$and $\mathrm{CdCl}_{2}{ }^{0}$ species in dependence on $\mathrm{NaCl}$ concentration in $1.0 \mathrm{~mol} / \mathrm{L} \mathrm{CdCl}_{2}$ in deionized water and $20^{\circ} \mathrm{C}$. Calculated by Visual MINTEQ ver. 3.0.
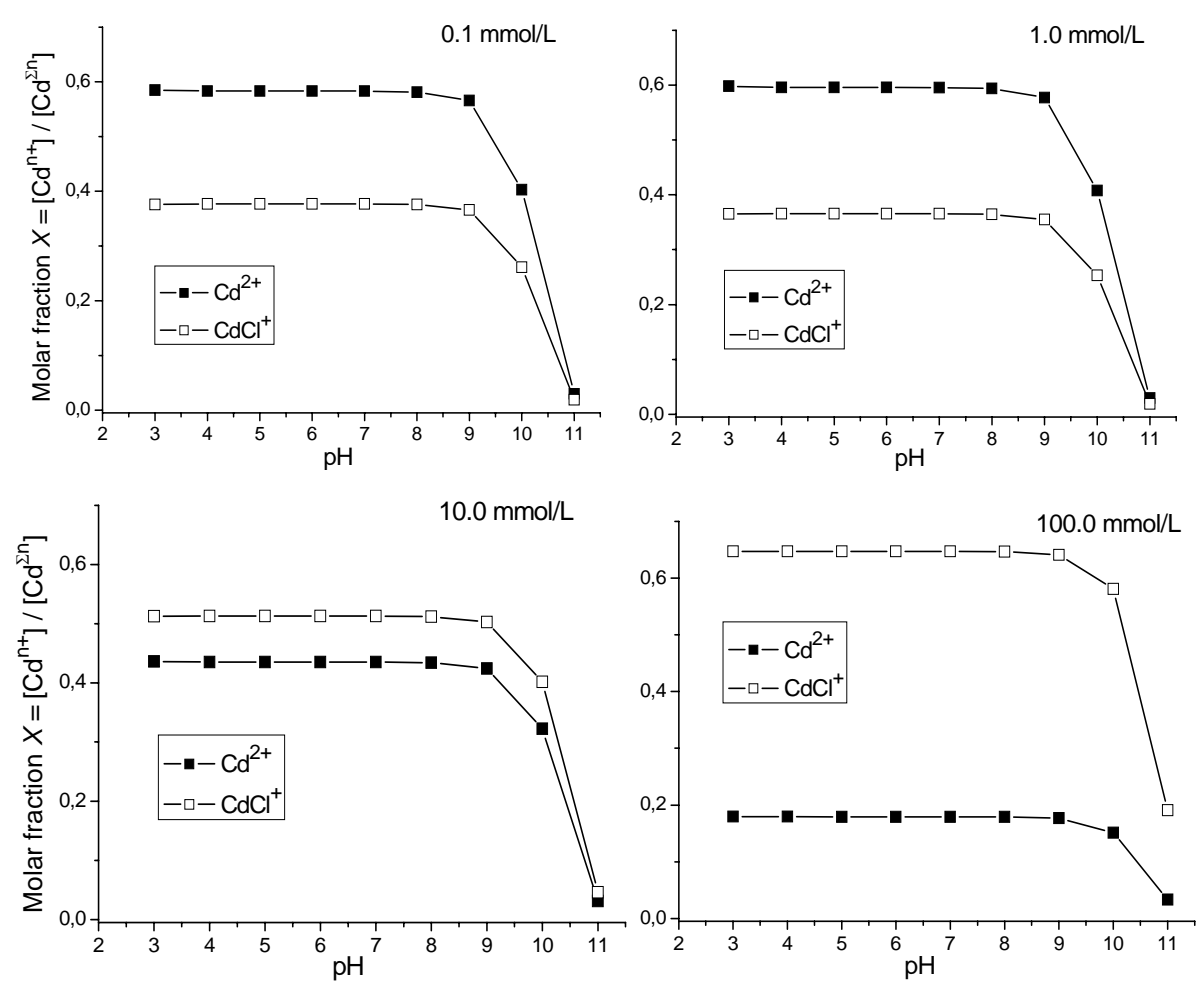

Fig. 4. pH dependence of molar fraction $X$ of $\mathrm{Cd}^{2+}$ and $\mathrm{CdCl}^{+}$ions at different $\mathrm{CdCl}_{2}$ concentration and $20^{\circ} \mathrm{C}$ in solution of inorganic salts simulating waste water according to IAQUINTA et al. (2006) (ppm): $\mathrm{Cl}^{-}$ - 455; $\mathrm{SO}_{4}{ }^{2-}-87 ; \mathrm{Na}^{+}-418 ; \mathrm{K}^{+}-78 ; \mathrm{Mg}^{2+}-45 ; \mathrm{Ca}^{2+}-138$. Calculated by Visual MINTEQ ver. 3.0. 


\subsection{Desorption}

In dependence on the [biomass]: [extractant] ratio, different percentage of cadmium can be removed. By extracting with deionized water at the [biomass]: $[$ extractant] $=1: 100(\mathrm{w} / \mathrm{v})$ ratio and in dependence on plant species up to $30 \% \mathrm{of} \mathrm{Cd}$ was removed by single step extraction at $20{ }^{\circ} \mathrm{C}$. By extraction with $0.1 \mathrm{~mol} / \mathrm{L}$ EDTA at [biomass]: [extractant] $=1: 20(\mathrm{w} / \mathrm{v})$ ratio, up to $85 \%$ and with $0.1 \mathrm{M} \mathrm{HCl}$ up to $98 \%$ was removed under identical conditions.

By desorption with water, new concentration equilibrium expressed as $P=[\mathrm{Cd}]_{\text {sorbent }}$ : $[\mathrm{Cd}]_{\text {solution }}$ is formed. Cadmium is released with higher efficiency from the binding sites of lower stability constants $\log K$. Stability constant of the metal complex can be described by the equation (2):

$$
\log K=[M L] /[M] *[L]
$$

where $K$ is the stability constant, $[M]$ is the concentration of $\mathrm{Cd}^{2+}$ ions and $[L]$ is the concentration of a ligand such as carboxylic or amino acids.

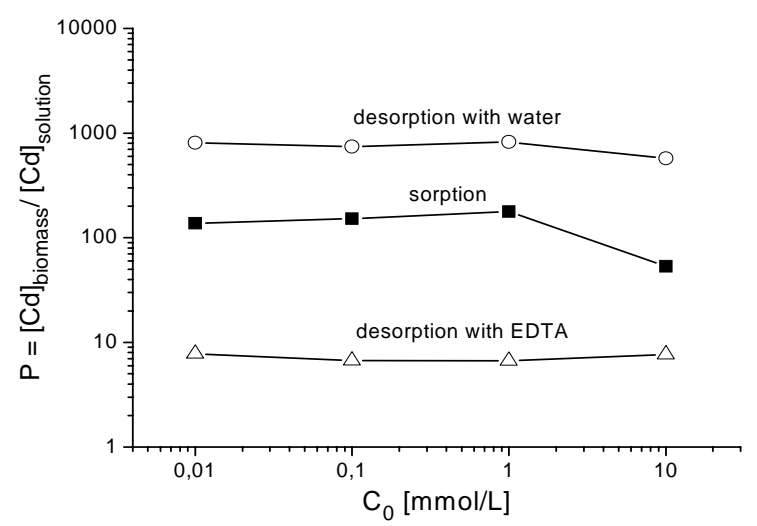

Fig. 5. Sorbent to solution concentration ratio $(\mathrm{mmol} / \mathrm{kg}) /(\mathrm{mmol} / \mathrm{L})$ for cadmium in dependence on initial concentration of $\mathrm{CdCl}_{2}$. Sorption process (- - - -$)$; desorption with deionized water $(-\mathrm{O}-\mathrm{O}-)$ and desorption with $0.1 \mathrm{~mol} / \mathrm{L}$ EDTA $(-\Delta-\Delta-)$. Experimental points are the mean values obtained from sorption experiments of 8 plants shown in Fig. 1 (---); and of data obtained by desorption of biomass with deionized water $\left(-\mathrm{O}_{-}-\mathrm{O}^{-}\right)$and $0.1 \mathrm{~mol} / \mathrm{L}$ EDTA as described in Materials and methods.

Metal ions can form more or less stable complexes with many biomolecules differing in stability constants $\log K$. Cd complexes with organic compounds can be divided into four groups. A: $\log K \sim 1-2$ (carboxylic acids); B: $\log K \sim 5-6$ (amino acids and citric acid); $\mathrm{C}: \log K \sim 9-10$ (cysteine, glutathione and other $-\mathrm{SH}$ compounds); D: $\log K \sim 16-18$ (complexing ligands such as EDTA). Classification is based on published data of $\mathrm{Cd}$ and other bivalent metal complexes (MARTELL and SMITH, 1964; SRIVASTAVA et al., 1993; GUNTHER and KASTENHOLZ, 2005).

We can suppose that by extracting with deionized water only $\mathrm{Cd}$ atoms bind into complexes of low $\log K$ values are released. Characterization of the mode of cadmium 
binding not extractable with the strongest ligands such as EDTA will require more detailed study. However differences in the efficiency of $\mathrm{Cd}$ desorption with water and EDTA reflects the fact that broad spectrum of reactive groups differing in stability constants is taking place.

\section{Conclusions}

Dried leaf biomass of eight vascular plants shows the sorption capacity for cadmium binding from $\mathrm{CdCl}_{2}$ water solution depending on the initial concentration of the solute, and is comparable with the sorption capacity of other sorbents of plant origin. Sorbed cadmium is partially leachable with deionized water and with high efficiency by EDTA solution and diluted mineral acids. This supports the idea that in sorption processes $\mathrm{Cd}$ complexes with different stability constants $\log K$ are formed. Calculation by speciation program Visual MINTEQ showed, that both alkaline $\mathrm{pH}$ values and concentration of chloride anions determines the existence at least seven $\mathrm{Cd}$ species with cationic, anionic and neutral charge. Obtained data can serve for the prediction of cadmium transport in biosphere and at penetration into food chain from contaminated vegetable crops.

\section{References}

BAILEY, S.E., OLIN, T.J., BRICKA, R.M., ADRIAN, D.D.: A review of potentially low-cost sorbents for heavy metals. Water Res., 33, 1999, 2469-2479.

GUIBAUD, G., VAN HULLEBUSCH, E., BORDAS, F., D'ABZAC, P., JOUSSEIN, E.: Sorption of $\mathrm{Cd}$ (II) and $\mathrm{Pb}$ (II) by exopolymeric substances (EPS) extracted from activated sludges and pure bacterial strains: Modelling of the metal/ligand ratio effect and role of the mineral fraction. Bioresour. Technol., 100, 2009, 29592968.

GUNTHER, K., KASTENHOLZ, B.: Speciation of cadmium in the environment and food. In: CORNELIS, R., CREWS, H., CARUSO, J., HEUMAN, K.G. (Eds.), Handbook of elemental speciation II: Species in the environment Food, Medicine and Occupational Health. John Wiley and Sons, Ltd. 2005, 745 pp.

HOAGLAND, D.R.: Optimum nutrient solutions for plants. Science, 52, 1920, $562-564$.

IAQUINTA, M., STOLLER, M., MERLI, C.: Development of synthetic wastewater from the tomato industry for membrane processing purposes. Desalination, 200, 2006, 739-741.

KABATA-PENDIAS, A., PENDIAS, H.: Trace Elements in Soils and Plants. $3^{\text {rd }}$ edition, CRC Press, Boca Raton, Florida, USA, 2001, 403 pp.

MAREŠOVÁ, J., HORNÍK, M., PIPÍŠKA, M., AUGUSTÍN, J.: Sorption of $\mathrm{Co}^{2+}$, $\mathrm{Zn}^{2+}, \mathrm{Cd}^{2+}$ and $\mathrm{Cs}^{+}$ions by activated sludge of sewage treatment plant. Nova Biotechnol., 10, 2010, 53-61.

MARTELL, A.E., SMITH, R.M.: Stability constants of metal ion complexes. (Special Supplement No. 17). Chemical Society, London, 1964, 754 pp. 
PIPÍŠKA, M., HORNÍK, M., REMENÁROVÁ, L., AUGUSTÍN, J., LESNÝ, J.: Biosorption of cadmium, cobalt and zinc by moss Rhytidiadelphus squarrosus in the single and binary component systems. Acta Chim. Slov., 57, 2010, 163-172.

PIPÍŠKA, M., HORNÍK, M., VRTOCH, L., AUGUSTÍN, J., LESNÝ, J.: Biosorption of $\mathrm{Zn}$ and Co ions by Evernia prunastri from single and binary metal solutions. Chem. Ecol., 24, 2008, 181-190.

SINGH, S., TRIPATHI, R.D. (Eds.): Environmental Bioremediation Technologies. Springer-Verlag, Berlin 2007, 518 pp.

SRIVASTAVA, S.K., GUPTA, V.K., TIWARI, B.B., ALI, I.: Electrophoretic determination of stability constants of $\mathrm{Zn}(\mathrm{II})-$ and $\mathrm{Cd}(\mathrm{II})-$ nitrilotriacetatepenicillamine mixed complexes. J. Chromatogr., 635, 1993, 171175.

SUD, D., MAHAJAN, G., KAUR, M.P.: Agricultural waste material as potential adsorbent for sequestering heavy metal ions from aqueous solutions - A review. Bioresour. Technol., 99, 2008, 6017-6027.

USEPA: US Environmental Protection Agency, Integrated Risk Information System (IRIS) on Cadmium, National Centre for Environmental Assessment, Office of Research and Development, Washington, DC, 1999. 